\begin{tabular}{c} 
Volume and Issues Obtainable at Center for Sustainability Research and Consultancy \\
Journal of Accounting and Finance in Emerging Economies \\
ISSN: 2519-0318 ISSN (E) 2518-8488 \\
Volume 5: No. 2, December 2019 \\
CSRᄃ \\
Journal homepage: www.publishing.globalcsrc.org/jafee \\
\hline
\end{tabular}

\title{
Mediating Role of Customer Trust in Predicting Customer Commitment through Automated Service Quality in Commercial Banking
}

\author{
${ }^{1}$ Shahar Yar, ${ }^{2}$ Jawad Hassan, ${ }^{3}$ Fatima Mazhar, ${ }^{4}$ Aisha Javeria \\ ${ }^{1}$ Virtual University of Pakistan: shaharyar7313@gmail.com \\ ${ }^{2}$ Virtual University of Pakistan \\ ${ }^{3}$ The Islamia University of Bahawalpur, Pakistan \\ ${ }^{4}$ The Islamia University of Bahawalpur, Pakistan
}

\begin{tabular}{l}
\multicolumn{1}{c}{ ARTICLE DETAILS } \\
\hline History \\
Revised format: November 2019 \\
Available Online:December 2019 \\
\\
\hline Keywords \\
Automated Service Quality, \\
Customer Commitment, Customer \\
Trust, Mediation
\end{tabular}

JEL Classification:

L15, L19, L84

\begin{abstract}
The automated service quality is a critical decider to scale customer commitment in commercial banking industry. Customer trust mediates the direct relationship among automated service quality and customer commitment. Customer trust in banking can be a competitive advantage for a service firm to compete in the market. Customer trust creates customer commitment and helps a bank to have new customers and sustain the existing ones. Current study explains the mediating role of customer trust while describing the relationship among automated service quality and customer commitment. Survey technique is used to collect data using an adopted questionnaire. Data analysis is done using Preacher and Hayes mediation method to prove the deducted hypothesis. The results demonstrate that features of online banking services create customer trust. Customer commitment of banking customers is mediated by the elements of customer trust, built on automated service quality features. These results have managerial and research implications for operations and strategy formulation in the banking industry. Results are valuable to smooth the provision of online services in the banks and financial institutions where information technologies are being used.
\end{abstract}

(C) 2019 The authors, under a Creative Commons AttributionNonCommercial 4.0

Corresponding author's email address: shaharyar7313@gmail.com

Recommended citation: Yar, S., Hassan, J., Mazhar. F. and Javeria, A., (2019). Mediating Role of Customer Trust in Predicting Customer Commitment through Automated Service Quality in Commercial Banking. Journal of Accounting and Finance in Emerging Economies, 5 (2), 275-294

DOI: $10.26710 /$ jafee.v5i2.935

\section{Introduction}

Service quality is a vital concept in marketing literature and it is considered as a tool to measure organizational performance and to shape the success of a business unit (Duncan \& Elliott, 2004; Litvin, Blose, \& Laird, 2005). Better quality of services gives positive outputs i.e. customer retention, customer attraction, positive word of mouth, increased productivity, growth in market share, decrease in staff 
turnover, decrease in operational cost and increase in employees' financial and moral performance (Johnston \& Kong, 2011). Therefore, service quality has become competitive edge for the services industries i.e. several banks provide the same products but the level of service they provide, differs largely. It is observed that service delivery is influenced by the use of technology (Dabholkar \& Bagozzi, 2002) and resultantly creates a substantial effect on service quality (Meuter, Ostrom, Roundtree, \& Bitner, 2000). Literature supports that the features of electronic commerce directly affect the gauge of service quality (Santos, 2003). Use of technology is critical in shaping buyer-seller experience (Parasuraman \& Grewal, 2000). Therefore, Automated Service Quality (ASQ) apprehensions in the banking industry are gaining importance day by day due to their ability to attract \& retain customers, increase sales \& profit and grab competitive advantage for the financial firms (Moutinho \& Smith, 2000; Nguyen \& LeBlanc, 1998). Combination of automated service delivery channels offers a user friendly package to the customers, instead of only one option i.e. manual or conventional banking services (Lang \& Colgate, 2003). Literature classifies internet, Automated Teller Machine (ATM) and phone banking as the basic automated service delivery channels in conventional banking industry (Joseph \& Stone, 2003). These automated services are used as complementary options to each other in the banking sector (Dabholkar \& Bagozzi, 2002). Banking customers use multiple automated services delivery options in a balancing way. Therefore, banks understand the need to motivate the customers for using automated services instead of off-line services (Berenson, Boyles, \& Weaver, 2008).

From a marketing perspective, banks must analyze customer perceptions and so design a service delivery mechanism to meet customers' needs \& optimize the level of service quality and performance in order to retain customers and further gain competitive advantage (Ramayah, Samat, \& Lo, 2011). Customer relationship building process is linked with the quality of automated services (Patrício, Fisk, \& Falcão e Cunha, 2003). Customers do evaluate these automated service options and mostly the decision to opt a particular service is affected by the quality of attributes attached with it (Dabholkar \& Bagozzi, 2002). Here we can say that automated services quality is important for banks to achieve organizational goals i.e. developing the competitive advantages, revenue generation, customer creation and customer retention (Fitzsimmons, Noh, \& Thies, 1998). It has been found in different studies that ASQ directly impacts Customer Commitment (CC) and Customer Loyalty (CL) (M. Al-Hawari \& Ward, 2006; Johnston \& Kong, 2011; Parasuraman, Zeithaml, \& Malhotra, 2005a).

State Bank of Pakistan (SBP), Pakistan's first central bank was established in 1948. Finance act of SBP was introduced in 1956 to encourage the private sector banking in the country. These financial reforms have improved the efficiency and performance of banks in Pakistan (Burki \& Niazi, 2003). Later on, the banking sector in Pakistan has succeeded to grow in 21st century, particularly in the past few years. Before the technology came into Pakistani banking, the policies and procedures of the banking were lengthy and difficult. In 90's banking systems were introduced by the information technology structures and this helped the customer to complete their financial and non-financial transactions without going to financial premises. Currently, phone banking, online banking, internet banking and virtual banking all are the latest baking channels being used by banking customers in Pakistan (Akhlaq \& Ahmed, 2013).

Modern technology in today's banking sector of Pakistan has increased customer attachment to the banks (Raza, Jawaid, \& Hassan, 2015). Technology factor has an impact on financial performance and customer services of the banks (Abubakar \& Tasmin, 2012). Online banking adoption attracts customers and leads to customer satisfaction which ultimately saves the time of the customers (Sikdar, Kumar, \& Makkad, 2015). The cost and time factors effect customer satisfaction while using automated services (Singh \& Kaur, 2013). Commitment factor is important for banking customers against the services being provided to them (Saleem, Zahra, Ahmad, \& Ismail, 2016). Therefore, the service quality options based on information technology modalities are critical in shaping customers' commitment (Mols, Nikolaj D. Bukh, \& Flohr Nielsen, 1999). Moreover, in developing countries like Pakistan, banking customers are more inclined by the factor of trust while dealing with internet banking (Akhlaq \& Ahmed, 2013). 
Commercial banking in Pakistan is having an intense competition since the privatization of the banking sector. The internet based banking services are still in the beginning phase in Pakistan. Therefore, banks are facing the issues of CT and CC deficit. The banks need customers who are committed, loyal and can create positive words of mouth for them. This deficit can only be decreased by establishing a relationship of trust between these stakeholders. Thus, there is a need to study ASQ of banks and its critical role in establishing the customers' commitment by enhancing their trust level.

\section{Research Questions:}

- What is the role of Automated Service Quality in influencing Customer Commitment in commercial banks?

- Does Customer Trust mediate the relationship between Automated Service Quality and Customer Commitment?

\section{Significance of Research}

The study would benefit the scholars and researchers who wish to explore different outcomes of ASQ. The study's empirical findings will enlighten the effective role of ASQ in enhancing CC of commercial banking customers. Additionally, the study's result will critically explain the mediating role of CT to affect the relationship between ASQ and CC. The findings of the study are valuable for banking authorities. They will be able to understand the critical importance of an efficient automated service system that can retain the trust of the customers and increase their commitment.

\section{Literature Review}

\subsection{Service Quality and Banking Services}

Service quality has great influence on a firm's business performances, i.e. lowering business expenses, enhancing business income and producing committed and trusted customers (Guru, Shanmugam, Alam, \& Perera, 2003; Sureshchandar, Rajendran, \& Anantharaman, 2002). Service firms must know their dynamic business requirements and should possess the market knowledge to sustain in a golbal market place (Sangeetha \& Mahalingam, 2011). In particular, service quality is now being treated as one of the major factors for measuring organizational performance, especially in the banking industry (Eisenberg, Hunt, Speer, \& Zivin, 2011). The banking sector is a growing sector, and banks are concerned with their repute and market share (Kumar, Mani, Mahalingam, \& Vanjikovan, 2010). Theoretical and empirical researches have established a strong relationship between firms' competitiveness and quality of services in banking (Sureshchandar et al., 2002). Service quality has been considered as an element for successful business growth in banking (Litvin et al., 2005) because customer sensitivity and shopping desire are finetuned by the bank's service delivery system (Ramayah et al., 2011). The literature has produced rigorous empirical and conceptual investigations of traditional service quality practices in the banking industry. A list of such conceptual models is being shared here for further clarity.

\section{Table 1 Service Quality Models}

\begin{tabular}{|l|l|l|l|}
\hline $\begin{array}{l}\text { Sr. } \\
\text { No. }\end{array}$ & $\begin{array}{l}\text { Model } \\
\text { Name/Title }\end{array}$ & Author & Short description \\
\hline 1 & GAP model & $\begin{array}{l}\text { (Parasuraman et al., } \\
\text { 2005a) }\end{array}$ & $\begin{array}{l}\text { Differences of customers expectations and } \\
\text { organizational performance along quality } \\
\text { dimensions decide the service quality of a firm. }\end{array}$ \\
\hline 2 & $\begin{array}{l}\text { Attributes of } \\
\text { Service quality } \\
\text { from customers' } \\
\text { perspective }\end{array}$ & $\begin{array}{l}\text { (Mersha \& Adlakha, } \\
\text { 1992) }\end{array}$ & $\begin{array}{l}\text { Identification and categorization of quality } \\
\text { attributes from the customer's perception. }\end{array}$ \\
\hline 3 & Service quality & (Ennew, Reed, \& & Measurement of service quality relies on the \\
\hline
\end{tabular}




\begin{tabular}{|c|c|c|c|}
\hline & $\begin{array}{l}\text { and performance } \\
\text { analysis }\end{array}$ & Binks, 1993) & $\begin{array}{l}\text { interaction of services to customer expectations } \\
\text { and provision of quality perceptions. }\end{array}$ \\
\hline 4 & $\begin{array}{l}\text { Satisfaction } \\
\text { factor and } \\
\text { Service quality }\end{array}$ & (Johnston, 1997) & $\begin{array}{l}\text { Distributive service quality factors effect on } \\
\text { customer satisfaction and dissatisfaction. }\end{array}$ \\
\hline 5 & $\begin{array}{l}\text { Technology and } \\
\text { service quality }\end{array}$ & $\begin{array}{l}\text { (Joseph, McClure, \& } \\
\text { Joseph, 1999) }\end{array}$ & $\begin{array}{l}\text { Impact of technology on service quality } \\
\text { perception in the banking industry. }\end{array}$ \\
\hline 6 & $\begin{array}{lr}\text { Service } & \text { quality } \\
\text { model } & \text { for } \\
\text { banking } & \end{array}$ & (Bahia \& Nantel, 2000) & $\begin{array}{l}\text { Measuring perceived quality of banking } \\
\text { services through banking service quality scale. }\end{array}$ \\
\hline 7 & SYSTRA-SQ & $\begin{array}{l}\text { (Aldlaigan \& Buttle, } \\
\text { 2002) }\end{array}$ & $\begin{array}{l}\text { Service quality perceived by consumers through } \\
\text { a four dimension scale }\end{array}$ \\
\hline 8 & $\begin{array}{l}\text { Automated } \\
\text { service quality }\end{array}$ & $\begin{array}{l}\text { (M. Al-Hawari, } \\
\text { Hartley, \& Ward, 2005) }\end{array}$ & $\begin{array}{l}\text { Delivery of banking automated services and } \\
\text { measuring customers satisfaction }\end{array}$ \\
\hline 9 & $\begin{array}{l}\text { Service quality } \\
\text { scale for banking }\end{array}$ & $\begin{array}{l}\text { (Karatepe, Yavas, \& } \\
\text { Babakus, 2005) }\end{array}$ & $\begin{array}{l}\text { Measurement of service quality provided to } \\
\text { bank customers' through their perception with } \\
\text { the help of four dimensional scales. }\end{array}$ \\
\hline 10 & $\begin{array}{l}\text { Perceived } \\
\text { service quality } \\
\text { and customer } \\
\text { expectations }\end{array}$ & $\begin{array}{l}\text { (Osayawe } \\
\text { 2006) }\end{array}$ & $\begin{array}{l}\text { Perceived service quality of customer } \\
\text { expectation and customers' loyalty prediction } \\
\text { from the bank. }\end{array}$ \\
\hline
\end{tabular}

Source: (Sangeetha \& Mahalingam, 2011)

Although multiple angles of service delivery constructs have been discussed in the literature, however, there is a notable difference in the context of e-banking (Abubakar \& Tasmin, 2012). Automated service delivery options in banking services includes ATM service, customer perception of price, telephone banking, banks' core service and internet banking (M. A. Al-Hawari, 2011). It has become deliberately vital for the banking sector to use these cheaper and faster automated services as alternative banking service delivery channels for high customer satisfaction and retention (Nui Polatoglu \& Ekin, 2001).

\subsection{Automated Service Quality}

There is a shift from conventional to automated service practices in recent years, as automated services have become effective distribution channels for banking customers (M. A. Al-Hawari, 2011). Banking customers are using multiple service delivery channels, i.e. manual and electronic in a complementary way (M. Al-Hawari \& Ward, 2006). Banks tend to craft few customer services which are available online and manageable through specific electronic means (Herington \& Weaven, 2007). An organization can strengthen its new service strategies and service improvements through automated services (Henderson, 2003). Automated service is defined as a web-based service, where customer's interaction with the firm is inevitable to the use of information technology (Surjadjaja, Ghosh, \& Antony, 2003). Furthermore, automated service is a visual based and internet built customers' service (Bloemer \& De Ruyter, 1998). Its qualities and attributes are different in the nature of each automated service delivery channel (Dabholkar \& Bagozzi, 2002). Within this context, ASQ has become a necessity for banks to provide timely and quality services to build and maintain successful, workable relationships with their valued customers.

\subsection{ASQ Model}

Automated Service Quality (ASQ) model is proposed by (Ibrahim, Joseph, \& Ibeh, 2006). This model includes factors of electronic service quality and summarizes all types of electronic banking into one account: responsiveness, convenience, personalization, security and queue management. 
Figure 1: Automated Service Quality Model no.2

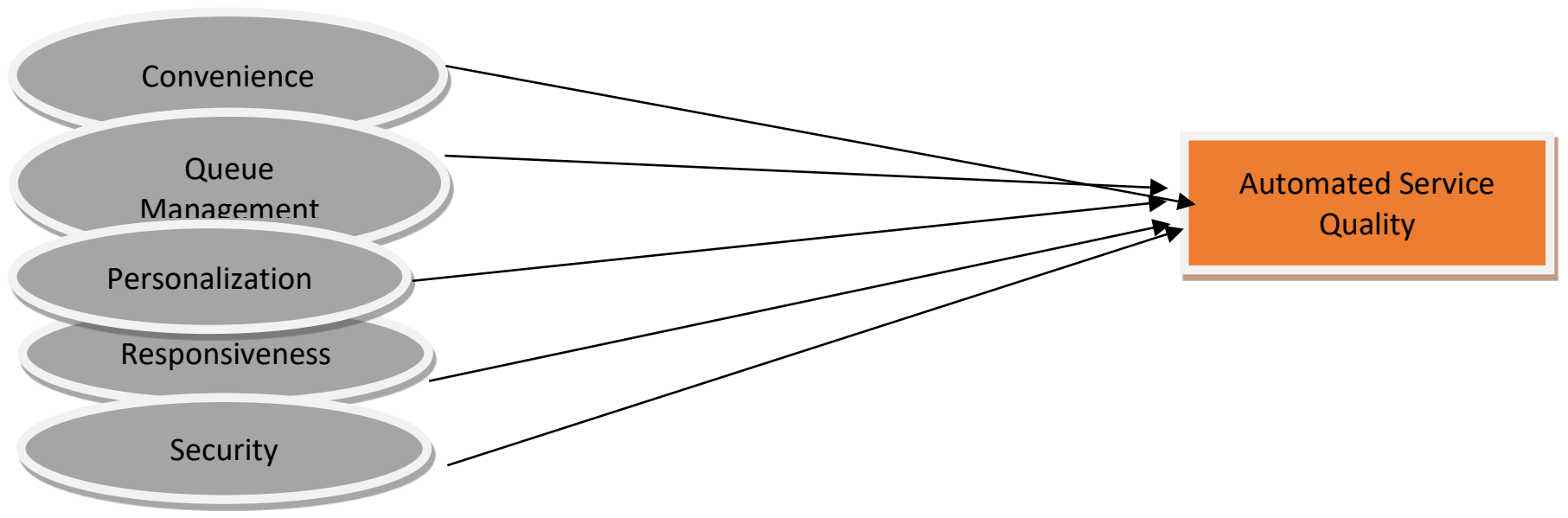

Source: (M. A. Al-Hawari, 2011)

\subsection{Dimension of Automated Service Quality}

There are five factors of the ASQ model presented by (Ibrahim et al.).

\subsubsection{Convenience}

Convenience is considered a vital aspect of customers' satisfaction (Dabholkar \& Bagozzi, 2002). Convenience is elaborated as ease \& usability of automated services, availability of services and service accuracy (Lovelock, Wirtz, \& Chew, 2009).

\subsubsection{Queue management}

Queue management is the ability of banking services to complete an automated transaction in a certain time limit. Bank customers review the quality of service from the speed of service delivery (Ibrahim et al., 2006).

\subsubsection{Personalization}

Personalization refers to the ability of an automated service to deal with a customer on individual basis. Personalization is an important factor in ASQ (Ananthanarayanan Parasuraman et al., 2005a). ASQ can be tailored according to the customers need and this accounts in the benefit of service quality (Yang, Jun, \& Peterson, 2004).

\subsubsection{Responsiveness}

Responsiveness is the measure of the ability of an automated service system of quickly handling customer complaints and problems. The act of response to the customer's objections has a major portion in customer satisfaction element (M. Al-Hawari \& Ward, 2006).

\subsubsection{Security}

Security means the ability of an automated service to keep the transaction safe and sound by keeping the confidentiality of the customers intact. Services with better security attract more customers (Rust \& Kannan, 2002).

\subsubsection{Automated Service Quality and Customer Commitment}


CC and CL have been discussed simultaneously as outcomes of ASQ in the literature (M. Al-Hawari \& Ward, 2006; Johnston \& Kong, 2011; Ananthanarayanan Parasuraman, Zeithaml, \& Malhotra, 2005b; Ribbink, Van Riel, Liljander, \& Streukens, 2004). CC and CL although seem connected but these are two different concepts (Chumpitaz Caceres \& Paparoidamis, 2007). Current study is focused to discuss CC instead of CL. Therefore, researcher needs to differentiate between these two adjacent concepts. CC is an stable desire of a customer to keep a valued relationship with the service provider (Moorman, Zaltman, \& Deshpande, 1992). Whereas; CL is a deeply held form of CC which motivates the buyer to repeat the previous buying, despite situational and marketing influences (Oliver, 1999). In the context of the problem statement of the current study, the writer is discussing the concept of $\mathrm{CC}$ here. CC is also important in comforting the behavior of customers irrespective of the changing situational conditions (Dash, Bruning, \& Ku Guin, 2009).There is no doubt that relationship strength is important for adding value to the business attitude of a service firm (Dash et al., 2009). For this, mutual commitment is a base to build strong relationships (A. Parasuraman \& Berry, 1991).

Above discussion concludes that CC is different from CL. In Pakistan, automated services being provided by the banks are still recent and most of its features are newly introduced. Therefore, it is more realistic for the banks to eye for CC rather than CL when dealing the customers who use ASQ tools frequently. It is also noticeable here that $\mathrm{CC}$ has been considered a very useful construct in the literature while measuring CL, forecasting consumers' purchase intentions and studying inter-organizational relationships.

Theoretically and empirically, literature gives the notion that ASQ creates progressive experiences among the users and increase the chances of continuing business with the bank (Zhu, Wymer, \& Chen, 2002). In a banking service, timely communication with customers, sharing the investment status, disclosing future opportunities \& risk, and expected financial outcomes add to the relationship commitment. CC between the banks and the customers is increased with a stronger communication in regard to their transactions handling, loan deposits, investments (Sharma and Patterson, 1999). Automated bank services are considered as an efficient method for providing timely and accurate information to customers. Bank customers can be updated with the information regarding their different financial transactions all the time. Nature of automated media, i.e. telephone, internet banking and ATM services push bank to timely inform customers and bridge the gap between customers and banks (Lang \& Colgate, 2003). CC between the banks and the customers is increased with a stronger communication in regard to their transactions handling (Sharma and Patterson, 1999). Attributed to computerized media, phone and electronic banking, the connections between customers and organizations have turned out to be nearer than any time in recent memory (Huff, 2012). Quality of automated service channels and their use decide the pattern of commitment by customers, loyalty of the customers and organization's overall increase in the market share (Brun, Rajaobelina, and Ricard, 2016). It is again emphasized that the quality of automated channels' services is an important way of maintaining CC and increase the market share (Joseph and Stone, 2003). The relationship between service quality and $\mathrm{CC}$ has been investigated only in some Business-2-Business (B2B) contexts or within the tangible goods services (Caceres \& Paparoidamis, 2007). However, less work has been done to investigate the relationship between bank ASQ and CC to their banks, especially in the case of developing economies.

Automated Service Quality and Customer Trust:

Trust is an essential ingredient in the relationship building process and being widely discussed in business studies (Ribbink et al., 2004). Trust is the name of confidence in someone's intentions and motives (Lewicki, McAllister, and Bies, 1998) and a key factor to establish long term relationship between an organization and its customers (Dash et al., 2009). Similarly to CC, the CT is another important factor for both business and the customers to have a good relationship. It enables to retain customers as if the CT is shaking so is the CC. CT is considered essential for building good relationships in terms of business discipline, (Dina, Reil Allard C.R., Veronica, and Sandra, 2004). 
Coulter and Coulter (2002) proposed that good signs of the service quality reduce the level of uncertainty among buyers. In the financial services sector, services are more complicated, and it is always not possible for customers to conclude and even remember their financial transactions. Therefore, clients are motivated on trust basis to retain a relationship with their banks (Sharma \& Patterson, 1999). Trust is a basic ingredient to balance the difference between customers' expectations and banks' offering, emerged due to the high risk factor in the services business and particularly in banks' automated services (Herington \& Weaven, 2007). The elements of risk within the automated service modules are higher than those within the traditional ones, so trust is considered as a critical factor to influence customer intentions within the context of e-commerce (Becerra \& Korgaonkar, 2011; Sahadev \& Purani, 2008). It is observed that a few studies have directly linked factors of e-service quality with CT (Sahadev \& Purani, 2008). There is a positive and significant relationship between banks' ASQ and CT (Ribbink et al., 2004).

\subsubsection{Customer Trust and Customer Commitment}

In accordance with the theory of (Morgan \& Hunt, 1994) it is clear that in a trust-commitment relationship, trust is a prerequisite of commitment. The trust is significant to build commitment (Chenet, Dagger, \& O'Sullivan, 2010) and this is particularly critical in the financial services context; where clients are more eager to continue their relationship, once having built trust and confidence in their bank's service ability (Sharma and Patterson, 1999). In the sector of business, it is known as an essential builder of a good relationship (Dimitriadis and Kyrezis, 2011; Dina et al., 2004; Trunfio et al., 2007). Banks must offer superior services to their valued customers as compared to their competitors and create a trust based relationship with their customers (Caceres \& Paparoidamis, 2007). When it comes to online services, the element of "lack of trust" becomes the main reason for not purchasing products and even services (Ribbink et al., 2004). Bank transactions done through automated services contain the risk of data theft, forgery or any other cyber-crime, so trust building is essential in creating a sustained and long-lasting relationship when there is a high perceived purchase or service risk (Herington and Weaven, 2007). (Chenet, Dagger, and O'Sullivan, 2010) found that trust has a direct relationship with commitment. In a services business, trust has been seen as particularly essential in retaining a long-lasting relationship (Amin, 2012; Chemingui \& Ben lallouna, 2013) particularly if we talk about bank automated services. Here we can argue that ASQ creates CT which is essential to generate CC. Although, ASQ positively increases $\mathrm{CC}$ but it is only possible when the element of $\mathrm{CT}$ is involved in the process.

\section{Theoretical Framework}

The researcher has crafted the following research framework in accordance with the literature and discussion.

Figure 2: Theoretical Framework of the study 


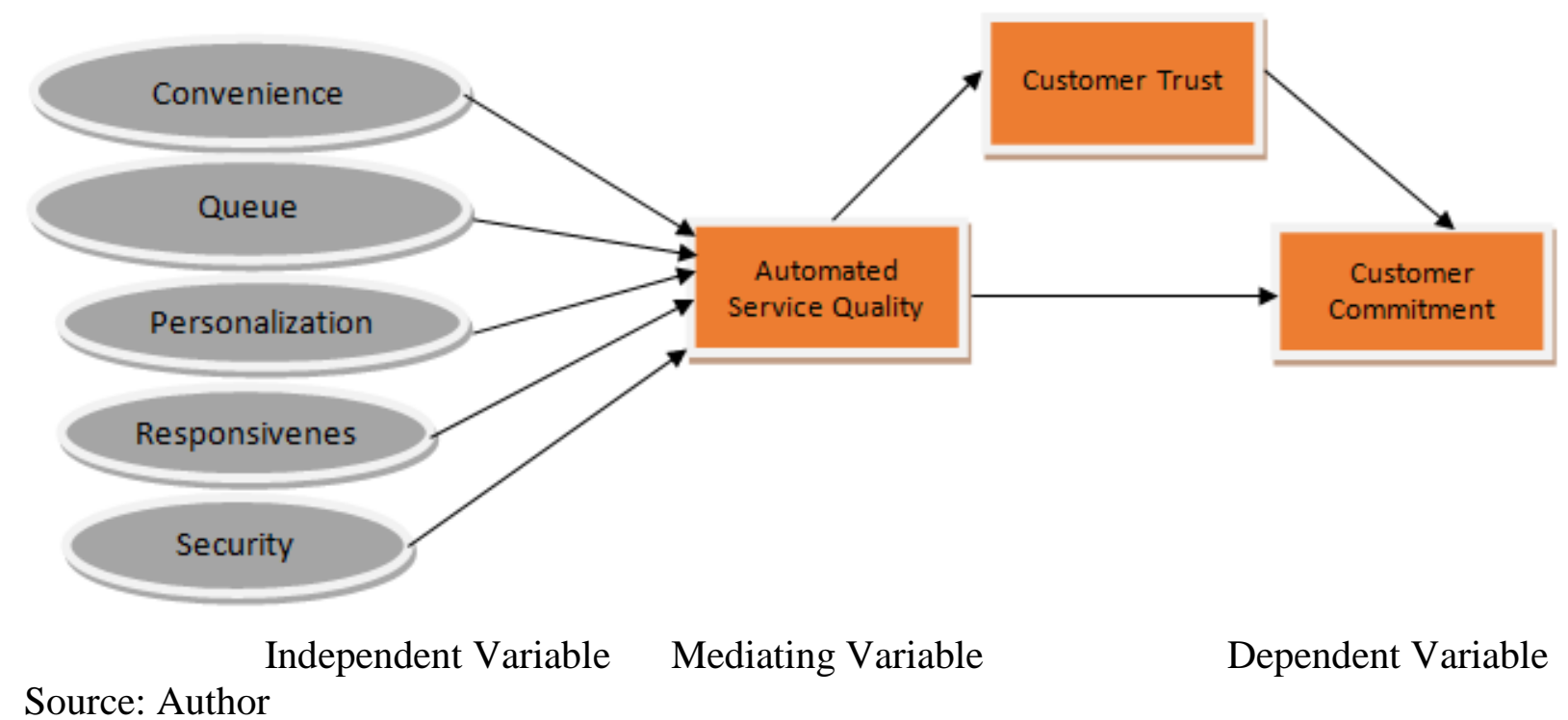

H1: Automated Service Quality has a significant effect on Customer Commitment

H2: Customer Trust mediates the relationship between Automated Service Quality and Customer Commitment

\section{Research Methodology}

In the current study, the researcher is following positivist approach to test the deduced hypothesis. Existing theory helps to deduct hypotheses which are tested using statistical measures (Bell, Bryman, \& Harley, 2018) by involving a highly structured methodology (Gill \& Johnson, 2010). Current study is a basic research. The researcher explains the mediating role of CT between ASQ and CC by testing the deducted hypothesis (Xia et al., 2003). Non-access to banks' customer database directs the use of nonprobability, convenience sampling technique (Farrokhi and Mahmoudi-Hamidabad, 2012). The sample size is 300 customers, determined by widely-cited rule of thumb from (Munro, 2005) specifying that the subject item ratio should be at least 10:1. The questionnaire has 28 items so sample size is rounded off to 300. The survey effective response rate is $81 \%$ with 245 valid returned questionnaires out of 300 . The researcher has adopted valid and well utilized questionnaires having 7 point likert scale.

The adopted survey contains the measurement of variables (automated service quality, customer trust and customer commitment). Automated service quality construct has five measuring dimensions i.e. convenience, queue management, personalization, responsiveness, and security) identified from the literature (Ibrahim et al., 2006; Ribbink et al., 2004; Loonam and O'Loughlin, 2008). Convenience has four items extracted from various studies such as Ibrahim et al. (2006) and Sahadev and Purani (2008). Queue management's has three items drawn from the studies of (Ibrahim et al., 2006; Al-Hawari and Ward, 2006). Four distinct items on personalization were produced from different studies such as (Ribbink et al., 2004; Coulter and Coulter, 2002; Herington and Weaven, 2007). Fours items for the measurement of responsiveness were extracted from the studies of (Yen and Lu, 2008; Loonam and O'Loughlin, 2008; Coulter and Coulter, 2002). Four items were extracted from the studies of (Loonam and O'Loughlin, 2008; Sahadev and Purani, 2008; Yen and Lu, 2008) to gauge security as a prominent factor of automated service quality measurement.

Five items were used in this study to measure customer trust were mainly adapted from Morgan and Hunt (1994), Sharma and Patterson (1999), and Caceres and Paparoidamis (2007). Four items were extracted from the literature to measure customer commitment (Dash et al., 2009; Morgan and Hunt, 1994; Sharma and Patterson, 1999; Caceres and Paparoidamis, 2007). 
The scale's overall reliability is excellent with 0.946 cronbach alpha value (George \& Mallery, 2003).

Table: 2 Measurement Items

\begin{tabular}{|c|c|c|c|}
\hline Variable & Dimensions & Items & Source \\
\hline \multirow{19}{*}{$\begin{array}{l}\text { Automated } \\
\text { Service } \\
\text { Quality }\end{array}$} & \multirow[t]{4}{*}{ Convenience } & $\begin{array}{l}\text { Banking requirements are available in the E- } \\
\text { banking menu. }\end{array}$ & \multirow{4}{*}{$\begin{array}{l}\text { Ibrahim et al. } \\
\text { (2006) } \\
\text { Sahadev and Purani } \\
(2008)\end{array}$} \\
\hline & & E-banking services are very easy to use. & \\
\hline & & $\begin{array}{l}\text { E-banking services have a user-friendly } \\
\text { system. }\end{array}$ & \\
\hline & & E-banking services are available $24 / 7$. & \\
\hline & \multirow[t]{3}{*}{$\begin{array}{l}\text { Queue } \\
\text { management }\end{array}$} & $\begin{array}{l}\text { E-banking provides a friendly environment, } \\
\text { including musical entertainment, to } \\
\text { customers in the queue. }\end{array}$ & \multirow{3}{*}{$\begin{array}{l}\text { Ibrahim et al. } \\
\text { (2006) } \\
\text { Al-Hawari and } \\
\text { Ward (2006) }\end{array}$} \\
\hline & & $\begin{array}{l}\text { E-banking provides other relevant } \\
\text { information about financial services to } \\
\text { customers waiting in the queue }\end{array}$ & \\
\hline & & $\begin{array}{l}\text { There is no waiting time involved in } \\
\text { obtaining } \\
\text { E-banking services }\end{array}$ & \\
\hline & \multirow[t]{4}{*}{ Personalizing } & $\begin{array}{l}\text { I feel that my personal needs have been met } \\
\text { when using my bank's different automated } \\
\text { options. }\end{array}$ & \multirow{4}{*}{$\begin{array}{l}\text { Ribbink et al. } \\
(2004) \\
\text { Coulter and Coulter } \\
(2002) \\
\text { Herington and } \\
\text { Weaven (2007) }\end{array}$} \\
\hline & & $\begin{array}{l}\text { My bank's automated options provide me } \\
\text { with information and products according to } \\
\text { my preferences }\end{array}$ & \\
\hline & & $\begin{array}{l}\text { My bank individualizes its e-mails regarding } \\
\text { the latest financial offers }\end{array}$ & \\
\hline & & $\begin{array}{l}\text { E-banking acknowledges me by name } \\
\text { during the transaction }\end{array}$ & \\
\hline & \multirow[t]{4}{*}{ Responsiveness } & $\begin{array}{l}\text { My bank is always interested in feedback } \\
\text { through the electronic channels }\end{array}$ & \multirow{4}{*}{$\begin{array}{l}\text { Yen and Lu (2008) } \\
\text { Loonam and } \\
\text { O'Loughlin (2008) } \\
\text { Coulter and Coulter } \\
(2002)\end{array}$} \\
\hline & & My bank quickly replies to online requests & \\
\hline & & $\begin{array}{l}\text { My banks constantly offers electronic } \\
\text { complaint forms }\end{array}$ & \\
\hline & & $\begin{array}{l}\text { My bank's automated services offer a real- } \\
\text { time communication option }\end{array}$ & \\
\hline & \multirow[t]{4}{*}{ Security } & $\begin{array}{l}\text { Elements of security are incorporated and } \\
\text { the customer is made aware of these }\end{array}$ & \multirow{4}{*}{$\begin{array}{l}\text { Loonam and } \\
\text { O'Loughlin (2008) } \\
\text { Sahadev and Purani } \\
\text { (2008) } \\
\text { Yen and Lu (2008) }\end{array}$} \\
\hline & & $\begin{array}{l}\text { My bank's automated services are } \\
\text { trustworthy }\end{array}$ & \\
\hline & & $\begin{array}{l}\text { I feel secure that my private information will } \\
\text { not go to another party }\end{array}$ & \\
\hline & & $\begin{array}{l}\text { The confidentiality of customer data is } \\
\text { ensured }\end{array}$ & \\
\hline \multirow[t]{2}{*}{ Commitment } & & I intend to maintain the relationship with my & \multirow{2}{*}{$\begin{array}{l}\text { Dash et al. (2009) } \\
\text { Morgan and Hunt } \\
(1994)\end{array}$} \\
\hline & & My relationship with my bank deserves & \\
\hline
\end{tabular}




\begin{tabular}{|c|c|c|}
\hline & maximum efforts to maintain & Sharma and \\
\hline & The relationship that I have with my bank is & Patterson (1999) \\
\hline & something I am very committed to & Caceres and \\
\hline & $\begin{array}{l}\text { I am very proud to have this bank as a } \\
\text { financial service provider }\end{array}$ & $\begin{array}{l}\text { Paparoidamis } \\
(2007)\end{array}$ \\
\hline Trust & My bank can be trusted always. & Morgan and Hunt \\
\hline & My bank can be counted on to do what is & $(1994)$ \\
\hline & right & Sharma and \\
\hline & My bank has a high moral soundness. & Patterson (1999) \\
\hline & My bank can be relied on to keep its words. & Caceres \\
\hline & I have feeling of trust in my bank & $\begin{array}{l}\text { Paparoidamis } \\
(2007)\end{array}$ \\
\hline
\end{tabular}

\subsection{Preacher and Hayes Method}

The researcher uses Preacher and Hayes method for mediation analysis to explain the mediation effect between the variables. It has further explanations for direct effect and indirect effect (Preacher \& Hayes, 2004). Direct effect $\left(\mathrm{c}^{\prime}\right)$ estimates the direct relationship between dependent and independent variables. Indirect effect estimates the relationship between independent and dependent variables via mediating variable. Indirect effect is consisted of the following sub parameters. Path a measures the change in mediating variable due to the independent variable. Path $b$ measures the change in dependent variable due to the mediating variable. Total effect (c) estimates the effect of the dependent variable on independent variable in the absence of mediator variable. It is to remember here the basic rule of mediation is that, the mediation occurs if strength of the relationship between the independent variable and dependent variable is reduced by including the mediator (Field, 2013).

\subsection{Sobel test Method}

Furthermore, sobel test is used to affirm the mediation effect of a variable under discussion. It tests whether the relationship between a predictor variable and an outcome variable is significantly reduced when a mediator is included in the model. It tests the indirect effect of the predictor on the outcome. Sobel test is also known as product of coefficients approach to inference or the delta method (Preacher \& Hayes, 2004).

\section{Data Analysis}

\subsection{Correlation Analysis}

Correlation investigation measures the connection between factors under examination. Table 4.1 tells the values of Pearson correlation (r) among study variables along with their significance values.

Table 2: Correlations

\begin{tabular}{|c|c|c|c|c|c|c|c|c|}
\hline & $\begin{array}{l}\text { Convenie } \\
\text { nce }\end{array}$ & $\begin{array}{l}\text { Queue } \\
\text { Managem } \\
\text { ent }\end{array}$ & $\begin{array}{l}\text { Personaliz } \\
\text { ing }\end{array}$ & $\begin{array}{l}\text { Responsive } \\
\text { ness }\end{array}$ & $\begin{array}{l}\text { Securi } \\
\text { ty }\end{array}$ & $\begin{array}{l}\text { Customer } \\
\text { Commitm } \\
\text { ent }\end{array}$ & $\begin{array}{l}\text { Custo } \\
\text { mer } \\
\text { Trust }\end{array}$ \\
\hline \multirow[t]{3}{*}{$\begin{array}{l}\text { Convenienc } \\
\mathrm{e}\end{array}$} & $\begin{array}{l}\text { Pearson } \\
\text { Correlat } \\
\text { ion }\end{array}$ & 1 & $.573 * *$ & $.460 * *$ & $.383^{* *}$ & $\begin{array}{l}.354 * \\
*\end{array}$ & $.433 * *$ & $.490^{* * *}$ \\
\hline & $\begin{array}{l}\text { Sig. (2- } \\
\text { tailed) }\end{array}$ & & .000 & .000 & .000 & .000 & .000 & .000 \\
\hline & $\mathrm{N}$ & 245 & 245 & 245 & 244 & 245 & 245 & 245 \\
\hline \multirow[t]{2}{*}{$\begin{array}{l}\text { Queue } \\
\text { Manageme } \\
\mathrm{nt}\end{array}$} & $\begin{array}{l}\text { Pearson } \\
\text { Correlat } \\
\text { ion }\end{array}$ & $.573 * *$ & 1 & $.594 * *$ & $.384 * *$ & $\begin{array}{l}.422 * \\
*\end{array}$ & $.530^{* *}$ & $.381 * *$ \\
\hline & Sig. (2- & .000 & & .000 & .000 & .000 & .000 & .000 \\
\hline
\end{tabular}




\begin{tabular}{|c|c|c|c|c|c|c|c|c|}
\hline & tailed) & & & & & & & \\
\hline & $\mathrm{N}$ & 245 & 245 & 245 & 244 & 245 & 245 & 245 \\
\hline \multirow[t]{3}{*}{$\begin{array}{l}\text { Personalizi } \\
\text { ng }\end{array}$} & $\begin{array}{l}\text { Pearson } \\
\text { Correlat } \\
\text { ion }\end{array}$ & $.460 * *$ & $.594 * *$ & 1 & $.539 * *$ & $\begin{array}{l}.481 * \\
*\end{array}$ & $.628 * *$ & $.416^{* *}$ \\
\hline & $\begin{array}{l}\text { Sig. (2- } \\
\text { tailed) }\end{array}$ & .000 & .000 & & .000 & .000 & .000 & .000 \\
\hline & $\mathrm{N}$ & 245 & 245 & 245 & 244 & 245 & 245 & 245 \\
\hline \multirow[t]{3}{*}{$\begin{array}{l}\text { Responsive } \\
\text { ness }\end{array}$} & $\begin{array}{l}\text { Pearson } \\
\text { Correlat } \\
\text { ion }\end{array}$ & $.383 * *$ & $.384 * *$ & $.539 * *$ & 1 & $\begin{array}{l}.564 * \\
*\end{array}$ & $.497 * *$ & $.480 * *$ \\
\hline & $\begin{array}{l}\text { Sig. (2- } \\
\text { tailed) }\end{array}$ & .000 & .000 & .000 & & .000 & .000 & .000 \\
\hline & $\mathrm{N}$ & 244 & 244 & 244 & 244 & 244 & 244 & 244 \\
\hline \multirow[t]{3}{*}{ Security } & $\begin{array}{l}\text { Pearson } \\
\text { Correlat } \\
\text { ion } \\
\end{array}$ & $.354 * *$ & $.422 * *$ & $.481 * *$ & $.564 * *$ & 1 & $.672 * *$ & $.627 * *$ \\
\hline & $\begin{array}{l}\text { Sig. (2- } \\
\text { tailed) }\end{array}$ & .000 & .000 & .000 & .000 & & .000 & .000 \\
\hline & $\mathrm{N}$ & 245 & 245 & 245 & 244 & 245 & 245 & 245 \\
\hline \multirow[t]{3}{*}{$\begin{array}{l}\text { Customer } \\
\text { Commitme } \\
\text { nt }\end{array}$} & $\begin{array}{l}\text { Pearson } \\
\text { Correlat } \\
\text { ion } \\
\end{array}$ & $.433 * *$ & $.530 * *$ & $.628 * *$ & $.497 * *$ & $\begin{array}{l}.672 * \\
*\end{array}$ & 1 & $.679 * *$ \\
\hline & $\begin{array}{l}\text { Sig. (2- } \\
\text { tailed) }\end{array}$ & .000 & .000 & .000 & .000 & .000 & & .000 \\
\hline & $\mathrm{N}$ & 245 & 245 & 245 & 244 & 245 & 245 & 245 \\
\hline \multirow[t]{3}{*}{$\begin{array}{l}\text { Customer } \\
\text { Trust }\end{array}$} & $\begin{array}{l}\text { Pearson } \\
\text { Correlat } \\
\text { ion }\end{array}$ & $.490 * *$ & $.381 * *$ & $.416^{* *}$ & $.480 * *$ & $\begin{array}{l}.627 * \\
*\end{array}$ & $.679 * *$ & 1 \\
\hline & $\begin{array}{l}\text { Sig. (2- } \\
\text { tailed) }\end{array}$ & .000 & .000 & .000 & .000 & .000 & .000 & \\
\hline & $\mathrm{N}$ & 245 & 245 & 245 & 244 & 245 & 245 & 245 \\
\hline
\end{tabular}

** Correlation is significant at the 0.01 level (2-tailed).

Table 2 depicts that correlation between $\mathrm{CT}$ and $\mathrm{CC}$ is 0.679 . This level of correlation indicates that CC and CT are positively related to each other in bank automated services. Furthermore, table 4.1 depicts the correlation between all dimensions of ASQ. A positive but moderately significant correlation is found between security and personalizing $(\mathrm{r}=0.481, \mathrm{p}=0.000)$. The result indicates that if security is given, then the customers move for personalizing. Lowest correlation is found between customers' trust and queue management that is $r=0.381$ this means queue management can have a negative impact on customer trust.

\subsection{Multi-Collinearity}

Correlation analysis initially inspects the multicollinearity among the variables. The extreme values must not exceed the terminal point of 0.80 to avoid multicollinearity. The analysis reveals clearly that none of the mentioned variables has the correlation coefficient valuing 0.80 or more hence multi-Collinearity doesn't exist among the listed variables.

\subsection{Frequency Analysis}


In the below table 3 it describes the frequency data analysis of bank customers who use automated service of the bank. Table shows that 106 people are having age 20-30 years who use bank automated services having high percentile of 43.3. 73 respondents are having age between 31-40 years making 29.8\%. Here the lowest age group is first one that is below the age of 20, and only 13 people use ASQ options here with the percentile of 5.3.

Table 3 Age Statistics

\begin{tabular}{|c|c|c|c|c|c|}
\hline & & Frequency & Percent & Valid Percent & Cumulative Percent \\
\hline \multirow[t]{6}{*}{ Valid } & $<20$ & 13 & 5.3 & 5.3 & 5.3 \\
\hline & $20-30$ & 106 & 43.3 & 43.3 & 48.6 \\
\hline & $31-40$ & 73 & 29.8 & 29.8 & 78.4 \\
\hline & $41-50$ & 35 & 14.3 & 14.3 & 92.7 \\
\hline & $51-60$ & 18 & 7.3 & 7.3 & 100.0 \\
\hline & Total & 245 & 100.0 & 100.0 & \\
\hline
\end{tabular}

Given below frequency table 4 is for monthly income of the customers who use automated services of their banks, here again we see that the second group is having high frequency regarding salaries between the range of 30000-50000 and their percentage is 35.9. The second high frequency is of the persons who are having salaries between 50000-70000 and that is near to 2nd group of salary income, this third group is having percentile of 29.8 as compare to first and fourth group of salary income that are on $22.0 \%$ and $12.2 \%$ respectively.

Table 4 Monthly Income Statistics:

\begin{tabular}{|l|l|l|l|l|l|}
\hline \multicolumn{2}{|c|}{} & Frequency & Percent & Valid Percent & $\begin{array}{l}\text { Cumulative } \\
\text { Percent }\end{array}$ \\
\hline \multirow{4}{*}{ Valid } & $<30000$ & 54 & & & 22.0 \\
\cline { 2 - 6 } & $30000-50000$ & 88 & 22.0 & 22.0 & 58.0 \\
\cline { 2 - 6 } & $50000-70000$ & 73 & 35.9 & 35.9 & 87.8 \\
\cline { 2 - 6 } & $>70000$ & 30 & 29.8 & 29.8 & 100.0 \\
\cline { 2 - 6 } & Total & 245 & 12.2 & 12.2 & \\
\hline
\end{tabular}

In the frequency table 5 we see that the male persons are more in frequency that is 147 as compared to female persons which is 98 , who use automated service of their banks. Male are having $60 \%$ while female are having $40 \%$ this also shows that male customers are more active in using bank automated services.

Table 5 Gender Statistics:

\begin{tabular}{|l|l|l|l|l|l|}
\hline \multicolumn{2}{|l|}{} & Frequency & Percent & Valid Percent & Cumulative Percent \\
\hline \multirow{3}{*}{ Valid } & Male & 147 & & & \\
\cline { 2 - 6 } & Female & 98 & 60.0 & 60.0 & 60.0 \\
\cline { 2 - 6 } & Total & 245 & 40.0 & 40.0 & 100.0 \\
\hline
\end{tabular}

The last frequency table 6 is qualification here. By analyzing this table we have found that majority of customers are master degree holder who are using automated services of the bank with the percentage of 46.1 and it is having frequency of 113 persons. Second most users of automated service from the banks 
Journal of Accounting and Finance in Emerging Economies

Vol.5, No 2, December 2019

are graduate persons with the frequency of 83 and their percentile is 33.9 . The lowest frequency is 15 that is considered in other qualification.

Table 6 Qualification Statistics:

\begin{tabular}{|l|l|l|l|l|l|}
\hline \multicolumn{2}{|l|}{} & Frequency & Percent & Valid Percent & $\begin{array}{l}\text { Cumulative } \\
\text { Percent }\end{array}$ \\
\hline \multirow{4}{*}{ Valid } & Matric & 18 & 7.3 & 7.3 & 7.3 \\
\cline { 2 - 6 } & Intermediate & 16 & 6.5 & 6.5 & 13.9 \\
\cline { 2 - 6 } & Graduation & 83 & 33.9 & 33.9 & 47.8 \\
\cline { 2 - 6 } & Master & 113 & 46.1 & 46.1 & 93.9 \\
\cline { 2 - 6 } & Other & 15 & 6.1 & 6.1 & 100.0 \\
\cline { 2 - 6 } & Total & 245 & 100.0 & 100.0 & \\
\hline
\end{tabular}

\subsection{Mediation Analysis}

The researcher has used Process macros embedded in SPSS to perform the mediation analysis as directed by (Preacher \& Hayes, 2004). Mediation analysis is being presented here step by step. Studied variables are tagged as:

- Automated Service Quality (ASQ) Independent Variable

- Customer Commitment (CC) Dependent Variable

- Customer Trust (CT) Mediating variable

Table 7 Direct effect (Path c'):

Outcome: CC Predictor: ASQ

Model Summary

$\begin{array}{ccccccc}\mathrm{R} & \mathrm{R}-\mathrm{sq} & \mathrm{MSE} & \mathrm{F} & \mathrm{df} 1 & \mathrm{df} 2 & \mathrm{p} \\ .7615 & .5800 & 5.0776 & 166.3719 & 2.00 & 241.00 & .0000\end{array}$

Model

$\begin{array}{lllcccc} & \text { Coeff } & \mathrm{se} & \mathrm{t} & \mathrm{p} & \text { LLCI } & \text { ULCI } \\ \text { Constant } & 2.8575 & .8003 & 3.5706 & .0004 & 1.2811 & 4.4339 \\ \text { CT } & .3041 & .0367 & 8.2876 & .0000 & .2318 & .3764 \\ \text { ASQ } & .1161 & .0141 & 8.2360 & .0000 & .0884 & .1439\end{array}$

Path c':

Table 7 describes Path c' i.e. direct effect of ASQ on CC. The given values show that there is a direct and positive relationship between ASQ the CC. The value of R2 $=.5800$ which shows that ASQ explains $58.00 \%$ variance in CC. P values is .0000 which shows that the relationship between ASQ and CC is significant. The value of coefficient beta is .1161 which shows that there is a positive relationship between ASQ and CC and one unit change in ASQ brings $11.61 \%$ or .1161 units positive change in CC.

These statistics prove H1 "Automated service quality has a significant effect on customer commitment"

Table 8 Path a:

Outcome: CT predictor: ASQ 
Model Summary

Model

$\begin{array}{ccccccc}\mathrm{R} & \mathrm{R}-\mathrm{sq} & \mathrm{MSE} & \mathrm{F} & \mathrm{df1} & \mathrm{df} 2 & \mathrm{p} \\ .5897 & .3478 & 15.5857 & 129.0383 & 1.0000 & 242.0000 & .0000\end{array}$

$\begin{array}{lllllll} & \text { Coeff } & \mathrm{se} & \mathrm{t} & \mathrm{p} & \text { LLCI } & \text { ULCI } \\ \text { Constant } & 8.5135 & 1.2909 & 6.5951 & .0000 & 5.9707 & 11.0563 \\ \text { ASQ } & .2266 & .0200 & 11.3595 & .0000 & .1873 & .2659\end{array}$

Table 8 path a shows the values for the predicted relationship between ASQ and CT. These values show that ASQ positively explains the CT. The R2 $=.3478$ which shows that ASQ explains $34.78 \%$ variance in CT.P values is .0000 which shows that the relationship between ASQ and CT is significant. The value of coefficient beta is .2266 which shows that there is a positive relationship between ASQ and CT and one unit change in ASQ brings $22.66 \%$ or .2266 units positive change in CT.

Path b:

Path $\mathrm{b}$ is shown in table 8. This is about the relationship between CT and CC. P value is .0000 which shows that the relationship between CT and CC is significant. The value of coefficient beta is .3041 which shows that there is a positive relationship between CT and CC and one unit change in CT brings $30.41 \%$ or .3041 units positive change in CC.

Table 9 Indirect Effect (ab):

Indirect effect of ASQ on CC through CT

\section{Effect Boot SE Boot LLCI Boot ULCI}

$\begin{array}{lllll}\text { CT } & .0689 & .0116 & .0487 & .0952\end{array}$

Table 9 explains the indirect effect of ASQ on CC through CT. The beta value is .0689 and it falls between 0.0487 and 0.0952 . The beta value interval does not contain zero, meaningfully, there is a genuine indirect effect. This notion confirms CT as a mediator variable between ASQ and CC.

Table 10 Total Effect (Path c):

Outcome: $\mathrm{CC}$

Model Summary

$\begin{array}{ccccccc}\text { R } & \text { R-sq } & \text { MSE } & \text { F } & \text { df1 } & \text { df2 } & \text { p } \\ .6784 & .4602 & 6.4977 & 206.3459 & 1.0000 & 242.0000 & .0000\end{array}$

Model

\begin{tabular}{|c|c|c|c|c|c|c|}
\hline & Coeff & $\mathrm{se}$ & $\mathrm{t}$ & p & LLCI & ULCI \\
\hline Constant & 5.4463 & 8335 & 6.5343 & .0000 & 3.8045 & 7.088 \\
\hline ASQ & .1851 & .0129 & 14.3647 & .0000 & 1597 & .2104 \\
\hline
\end{tabular}

In above table 10 path $\mathrm{c}$ is being explained. It is also called total effect of ASQ on CM through CT. The given values show that there is a direct and positive relationship between ASQ the CM when coming through CT. The R2 $=.4602$ which shows that ASQ explains $46.02 \%$ variance in CM. P values is .0000 which shows that the relationship between ASQ and CM is significant. The value of coefficient beta is .19 which shows that there is a positive relationship between ASQ and CM and one unit change in ASQ brings $18.51 \%$ or .1851 units positive change in CM.

Figure 3: Mediation Results Interpretation: 


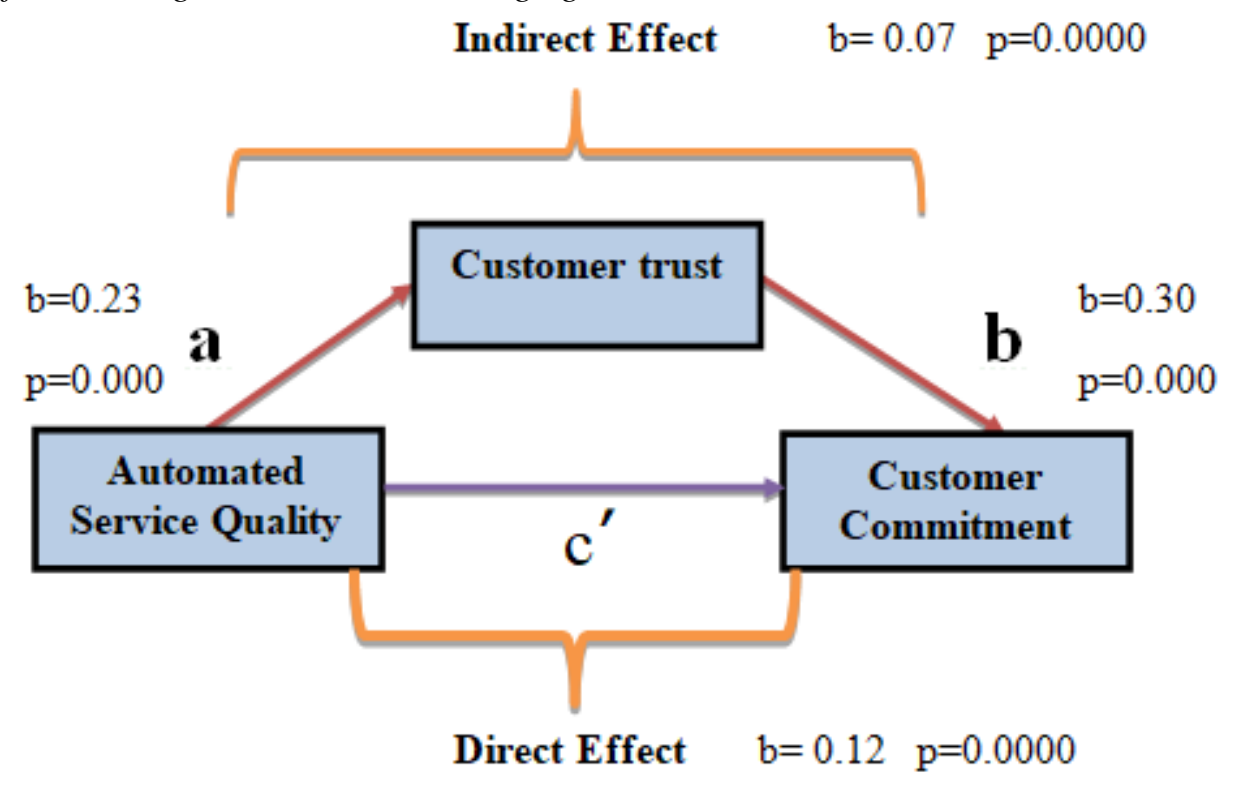

The above mediation model is same as (Field, 2013) and it is explaining the direct and indirect effects with the relationship among the variables whereas ASQ is independent variable, CM is dependent and CT is a mediating variable. The relationship of ASQ to CT and CM is direct as well as relationship of CT to $\mathrm{CM}$ is also direct and positive as the level of significance $\mathrm{p}=0.000$ in both cases: direct and indirect effects. It means as ASQ increases then the CT will increase and this will subsequently lead to increase CM. This result initially testifies the role of $\mathrm{CT}$ as a mediating variable. For cross verification it is necessary to check that.

Indirect effect $(0.07)=($ Path a 0.23) $\times($ Path b 0.30)

Total effect $\mathrm{c}(0.19)=\left(\right.$ Direct effect $\left.c^{\prime} 0.12\right)+($ Indirect effect 0.07$)$

These statistics prove $\mathrm{H} 2$ "Customer trust mediates the relationship between automated service quality and customer commitment"

\subsection{Sobel Test}

Sobel test statistics are being presented here to further affirm the mediating role of the variable under discussion. Table11 tells that we are getting the same beta value as effect .0689 and level of significance $\mathrm{p}=0.000$. This is compelling evidence that $\mathrm{CT}$ is a mediating variable.

Table 11 Sobel test

Normal theory tests for indirect effect

$\begin{array}{rccr}\text { Effect } & \text { se } & \mathrm{Z} & \mathrm{p} \\ .0689 & .0103 & 6.6783 & .0000\end{array}$

\section{Discussion}

\subsection{Research Question1}

What is the role of Automated Service Quality in influencing customers' commitment in commercial banks?

According to table 7 direct effect( $\left.\mathrm{c}^{\prime}\right)$ we see that ASQ is having a significant influence on CC. The table describes regression value of $58.00 \%$ and level of significance is 0.000 . It proves $\mathrm{H} 1$ i.e. there is positive relationship between ASQ and CM. Descriptive statistics of the study indicate that convenience, queue 
management, personalizing, responsiveness and security elements contribute to ASQ and these dimensions subsequently affect the magnitude of commitment of banking customers. Automated services facilitate customers by increasing user convenience level in banking services. Better quality of automated services increases system responsiveness towards customers. Better queue management reduces time delays in service delivery and it saves customers time and extra effort to complete their banking transactions. It also helps customers to get resolve their customer service issues and increases the effectiveness of grievances handling complaints. These results are in line with the previous studies of (Hoehle, Scornavacca, \& Huff, 2012; Lang \& Colgate, 2003) found that the increased availability of electronically mediated self-service technologies in the banking industry has customers' inclination trend towards a bank. It has been found in various studies that the presence of a user friendly banking environment increases customer commitment. Being the residents of an underdeveloped area the southern Punjab customers find it attractive to have all their banking needs online and readily available.

Customers' commitment towards a particular bank is influenced by the volume of agility and effectiveness of bank's response towards their queries and nonstop service provision. Study results verify that the element of security in terms of customers' personal data usage, data sharing and surveillance is a deciding factor to gauge the quality of automated services. System's security factor has emerged as a prompt factor among the dimensions of automated service quality. A secure network increases customers' commitment towards using that particular bank's services in the future. The same relationship has been discussed by (Chemingui \& Ben lallouna, 2013) that trust is based on security and responsiveness of the service providing firm.

\subsection{Research Question 2}

Does customer trust mediate the relationship between Automated Service Quality and customer commitment?

In data analysis section table 8 path a shows the values for the predicted relationship between ASQ and $\mathrm{CT}$. These values show that ASQ positively explains with $\mathrm{R} 2=.3478$ and $\mathrm{P}=.0000$ with beta $=.2266$. From the analysis we see that customers' trust mediates the relationship between automated service quality and customer commitment directly and indirectly as well. Here ASQ predicts customer trust; each dimensions of ASQ are linked with customer trust except queue management. Results show that ASQ dimensions i.e. convenience, responsiveness, security and personalization have significance impact on customers' trust as if these dimensions are not provided to customers or any of them is lacking to provide what they are meant to, the level of trust will decrease as the trust will decrease the relation between ASQ and CT will decline ultimately. The findings of the study are in line with studies of (Chemingui \& Ben lallouna, 2013; Chenet et al., 2010; Henderson, 2003) who collectively argue that banking customers' trust is effected by the quality of automated services being offered by the bank.

The table 9 explains the indirect effect of ASQ on CT through CM. The given values show that there is a direct and positive relationship between ASQ the CM as indirect effect is .0689 with beta $=.116$. The given analysis of this research shows that quality automated service increases the trust and the customer commitment also increases. These results relate to the previous studies such as indirect effect explains, the combined effect of ASQ and CT on CM is evident to enhance customers' commitment through customers' trust (Becerra \& Korgaonkar, 2011; Sahadev \& Purani, 2008). Here mutual commitment is inspired by the amount of trust and it is a base to build strong relationships and then convert it in a valued relationship (Dash et al., 2009). Our results are perfectly in accordance with the theory of Morgan and Hunt (1994) arguing that trust is a prerequisite factor for commitment. Trust has direct relationship with commitment (Chenet et al., 2010).

\section{Conclusion}


This study is aimed to explain the impact of ASQ on CC via mediating role of CT among banking customers of southern Punjab Pakistan. The study is conducted in the banks where automated services like ATM, internet banking, telephone banking and mobile banking are being provided to the customers. The study concludes that as ASQ increases, the CT increases and subsequently CC is increased. ASQ has a significant effect on CC and CT simultaneously. Precisely, CT mediates the relationship between ASQ and CC.

\section{Limitations and Recommendations of the Study}

Limitations and future suggestions of the study are as below.

- Current study is focused only on banks with technology based service quality options. The financial sector also includes non-banking organizations such as investment banks, insurance companies, brokerage houses etc. More scientific studies can be conducted in a broader scope for banking and non-banking organizations and where information technologies are being used as a core service medium. Apart from sector specific study, generalized studies can also be conducted by keeping generic definition of automated services in non-banking industries.

- Moreover this study was conducted on the banking industry of southern Punjab and it can be further extended to other under-developed areas of Punjab. The study conducted in the under-developed area may posit unique results.

- The construct of automated service quality being studied in the current study have five dimensions. Furthermore, model of automated service quality can add or further extend the scope of the study by including the factors such as cost and rapid change in technology factor etc.

- This study can serve as a base to the new and existing organizations which are planning to launch their automated service technologies in market, as in this age of competition, no one would like to take blind step, as cost of IT is too high for implementation.

- The impact of customers' trust on the automated services can be investigated by taking other directing (moderating) or intervening (mediating) variables in the model like culture, monetary conditions, item life cycle etc.

\section{References}

Abubakar, A. A., \& Tasmin, R. B. H. (2012). The impact of information and communication technology on banks' performance and customer service delivery in the banking industry. International Journal of Latest Trends in Finance and Economic Sciences, 2(1).

Akhlaq, A., \& Ahmed, E. (2013). The effect of motivation on trust in the acceptance of internet banking in a low income country. International Journal of Bank Marketing, 31(2), 115-125.

Aldlaigan, A. H., \& Buttle, F. A. (2002). SYSTRA-SQ: a new measure of bank service quality. International Journal of Service Industry Management, 13(4), 362-381.

Al-Hawari, M. A. (2011). Automated service quality as a predictor of customers' commitment: a practical study within the UAE retail banking context. Asia Pacific Journal of Marketing and Logistics, 23(3), 346-366.

Al-Hawari, M., Hartley, N., \& Ward, T. (2005). Measuring Banks' Automated Service Quality: A Confirmatory Factor Analysis Approach. Marketing Bulletin, 16.

Al-Hawari, M., \& Ward, T. (2006). The effect of automated service quality on Australian banks' financial performance and the mediating role of customer satisfaction. Marketing Intelligence \& Planning, 24(2), $127-147$.

Amin, H. (2012). Explaining intention to use the Islamic credit card: an extension of the TRA model. University Library of Munich, Germany.

Bahia, K., \& Nantel, J. (2000). A reliable and valid measurement scale for the perceived service quality of banks. International Journal of Bank Marketing, 18(2), 84-91.

Baron, R. M., \& Kenny, D. A. (1986). The moderator-mediator variable distinction in social psychological research: Conceptual, strategic, and statistical considerations. Journal of Personality and Social Psychology, 51(6), 1173.

Becerra, E. P., \& Korgaonkar, P. K. (2011). Effects of trust beliefs on consumers' online intentions. European Journal of Marketing, 45(6), 936-962. 
Bell, E., Bryman, A., \& Harley, B. (2018). Business research methods. Oxford university press.

Berenson, R., Boyles, G., \& Weaver, A. (2008). Emotional intelligence as a predictor of success in online learning. The International Review of Research in Open and Distributed Learning, 9(2).

Blanchard, R. F., \& Galloway, R. L. (1994). Quality in retail banking. International Journal of Service Industry Management, 5(4), 5-23.

Bloemer, J., \& De Ruyter, K. (1998). On the relationship between store image, store satisfaction and store loyalty. European Journal of Marketing, 32(5/6), 499-513.

Bryman, A. (2015). Social research methods. Oxford university press.

Burki, A. A., \& Niazi, G. S. K. (2003). The effects of privatization, competition and regulation on banking efficiency in Pakistan, 1991-2000. In Regulatory Impact Assessment: Strengthening Regulation Policy and Practice, Chancellors Conference Centre, University of Manchester, Manchester, UK.

Chemingui, H., \& Ben lallouna, H. (2013). Resistance, motivations, trust and intention to use mobile financial services. International Journal of Bank Marketing, 31(7), 574-592.

Chenet, P., Dagger, T. S., \& O'Sullivan, D. (2010). Service quality, trust, commitment and service differentiation in business relationships. Journal of Services Marketing, 24(5), 336-346.

Chumpitaz Caceres, R., \& Paparoidamis, N. G. (2007). Service quality, relationship satisfaction, trust, commitment and business-to-business loyalty. European Journal of Marketing, 41(7/8), 836-867.

Dabholkar, P. A., \& Bagozzi, R. P. (2002). An attitudinal model of technology-based self-service: moderating effects of consumer traits and situational factors. Journal of the Academy of Marketing Science, 30(3), 184-201.

Dash, S., Bruning, E., \& Ku Guin, K. (2009). A cross-cultural comparison of individualism's moderating effect on bonding and commitment in banking relationships. Marketing Intelligence \& Planning, 27(1), 146-169.

Duncan, E., \& Elliott, G. (2004). Efficiency, customer service and financial performance among Australian financial institutions. International Journal of Bank Marketing, 22(5), 319-342.

Eisenberg, D., Hunt, J., Speer, N., \& Zivin, K. (2011). Mental health service utilization among college students in the United States. The Journal of Nervous and Mental Disease, 199(5), 301-308.

Ennew, C. T., Reed, G. V., \& Binks, M. R. (1993). Importance-performance analysis and the measurement of service quality. European Journal of Marketing, 27(2), 59-70.

Field, A. (2013). Discovering statistics using IBM SPSS statistics. sage.

Fitzsimmons, J. A., Noh, J., \& Thies, E. (1998). Purchasing business services. Journal of Business \& Industrial Marketing, 13(4/5), 370-380.

George, D., \& Mallery, M. (2003). Using SPSS for Windows step by step: a simple guide and reference.

Gill, J., \& Johnson, P. (2010). Research methods for managers. Sage.

Guru, B. K., Shanmugam, B., Alam, N., \& Perera, C. J. (2003). An evaluation of internet banking sites in Islamic countries. Journal of Internet Banking and Commerce, 8(2), 1-11.

Henderson, V. (2003). The urbanization process and economic growth: The so-what question. Journal of Economic Growth, 8(1), 47-71.

Herington, C., \& Weaven, S. (2007). Can banks improve customer relationships with high quality online services? Managing Service Quality: An International Journal, 17(4), 404-427.

Hoehle, H., Scornavacca, E., \& Huff, S. (2012). Three decades of research on consumer adoption and utilization of electronic banking channels: A literature analysis. Decision Support Systems, 54(1), 122-132.

Ibrahim, E. E., Joseph, M., \& Ibeh, K. I. (2006). Customers' perception of electronic service delivery in the UK retail banking sector. International Journal of Bank Marketing, 24(7), 475-493.

Johnston, R. (1997). Identifying the critical determinants of service quality in retail banking: importance and effect. International Journal of Bank Marketing, 15(4), 111-116.

Johnston, R., \& Kong, X. (2011). The customer experience: a road-map for improvement. Managing Service Quality: An International Journal, 21(1), 5-24.

Joseph, M., McClure, C., \& Joseph, B. (1999). Service quality in the banking sector: the impact of technology on service delivery. International Journal of Bank Marketing, 17(4), 182-193.

Joseph, M., \& Stone, G. (2003). An empirical evaluation of US bank customer perceptions of the impact of technology on service delivery in the banking sector. International Journal of Retail \& Distribution Management, 31(4), 190-202.

Karatepe, O. M., Yavas, U., \& Babakus, E. (2005). Measuring service quality of banks: Scale development and validation. Journal of Retailing and Consumer Services, 12(5), 373-383.

Kemal Avkiran, N. (1994). Developing an instrument to measure customer service quality in branch banking. 
International Journal of Bank Marketing, 12(6), 10-18.

Kumar, S. A., Mani, B., Mahalingam, S., \& Vanjikovan, M. (2010). Influence of Service Quality on Attitudinal Loyalty in Private Retail Banking: An Empirical Study. IUP Journal of Management Research, 9(4).

Lang, B., \& Colgate, M. (2003). Relationship quality, on-line banking and the information technology gap. International Journal of Bank Marketing, 21(1), 29-37.

Litvin, S. W., Blose, J. E., \& Laird, S. T. (2005). Tourists' use of restaurant webpages: Is the internet a critical marketing tool? Journal of Vacation Marketing, 11(2), 155-161.

Lovelock, C. H., Wirtz, J., \& Chew, P. (2009). Essentials of services marketing.

Mersha, T., \& Adlakha, V. (1992). Attributes of service quality: the consumers' perspective. International Journal of Service Industry Management, 3(3), 34-45.

Meuter, M. L., Ostrom, A. L., Roundtree, R. I., \& Bitner, M. J. (2000). Self-service technologies: understanding customer satisfaction with technology-based service encounters. Journal of Marketing, 64(3), 50-64.

Mols, N. P. (1998). The behavioral consequences of PC banking. International Journal of Bank Marketing, 16(5), 195-201.

Mols, N. P., Nikolaj D. Bukh, P., \& Flohr Nielsen, J. (1999). Distribution channel strategies in Danish retail banking. International Journal of Retail \& Distribution Management, 27(1), 37-47.

Moorman, C., Zaltman, G., \& Deshpande, R. (1992). Relationships between providers and users of market research: The dynamics of trust. Journal of Marketing Research, 29(3), 314-328.

Morgan, R. M., \& Hunt, S. D. (1994). The commitment-trust theory of relationship marketing. The Journal of Marketing, 20-38.

Moutinho, L., \& Smith, A. (2000). Modelling bank customer satisfaction through mediation of attitudes towards human and automated banking. International Journal of Bank Marketing, 18(3), 124-134.

Munro, B. H. (2005). Statistical methods for health care research (Vol. 1). lippincott williams \& wilkins.

Nguyen, N., \& LeBlanc, G. (1998). The mediating role of corporate image on customers' retention decisions: an investigation in financial services. International Journal of Bank Marketing, 16(2), 52-65.

Nui Polatoglu, V., \& Ekin, S. (2001). An empirical investigation of the Turkish consumers' acceptance of Internet banking services. International Journal of Bank Marketing, 19(4), 156-165.

Oliver, R. L. (1999). Whence consumer loyalty? The Journal of Marketing, 33-44.

Osayawe Ehigie, B. (2006). Correlates of customer loyalty to their bank: a case study in Nigeria. International Journal of Bank Marketing, 24(7), 494-508.

Parasuraman, A., \& Berry, L. L. (1991). Marketing services: competing through quality. New York.

Parasuraman, Ananthanarayanan, Zeithaml, V. A., \& Malhotra, A. (2005a). ES-QUAL: A multiple-item scale for assessing electronic service quality. Journal of Service Research, 7(3), 213-233.

Parasuraman, Ananthanarayanan, Zeithaml, V. A., \& Malhotra, A. (2005b). ES-QUAL: A multiple-item scale for assessing electronic service quality. Journal of Service Research, 7(3), 213-233.

Parasuraman, \& Grewal, D. (2000). The impact of technology on the quality-value-loyalty chain: a research agenda. Journal of the Academy of Marketing Science, 28(1), 168-174.

Patrício, L., Fisk, R. P., \& Falcão e Cunha, J. (2003). Improving satisfaction with bank service offerings: measuring the contribution of each delivery channel. Managing Service Quality: An International Journal, 13(6), 471482.

Preacher, K. J., \& Hayes, A. F. (2004). SPSS and SAS procedures for estimating indirect effects in simple mediation models. Behavior Research Methods, Instruments, \& Computers, 36(4), 717-731.

Ramayah, T., Samat, N., \& Lo, M.-C. (2011). Market orientation, service quality and organizational performance in service organizations in Malaysia. Asia-Pacific Journal of Business Administration, 3(1), 8-27.

Raza, S. A., Jawaid, S. T., \& Hassan, A. (2015). Internet banking and customer satisfaction in Pakistan. Qualitative Research in Financial Markets, 7(1), 24-36.

Ribbink, D., Van Riel, A. C., Liljander, V., \& Streukens, S. (2004). Comfort your online customer: quality, trust and loyalty on the internet. Managing Service Quality: An International Journal, 14(6), 446-456.

Rust, R. T., \& Kannan, P. K. (2002). E-service: New directions in theory and practice. ME Sharpe.

Sahadev, S., \& Purani, K. (2008). Modelling the consequences of e-service quality. Marketing Intelligence \& Planning, 26(6), 605-620.

Saleem, M. A., Zahra, S., Ahmad, R., \& Ismail, H. (2016). Predictors of customer loyalty in the Pakistani banking industry: a moderated-mediation study. International Journal of Bank Marketing, 34(3), 411-430.

Sangeetha, J., \& Mahalingam, S. (2011). Service quality models in banking: a review. International Journal of 
Islamic and Middle Eastern Finance and Management, 4(1), 83-103.

Santos, J. (2003). E-service quality: a model of virtual service quality dimensions. Managing Service Quality: An International Journal, 13(3), 233-246.

Sharma, N., \& Patterson, P. G. (1999). The impact of communication effectiveness and service quality on relationship commitment in consumer, professional services. Journal of Services Marketing, 13(2), 151170.

Sikdar, P., Kumar, A., \& Makkad, M. (2015). Online banking adoption: A factor validation and satisfaction causation study in the context of Indian banking customers. International Journal of Bank Marketing, 33(6), 760-785.

Singh, J., \& Kaur, P. (2013). Customers' attitude towards technology based services provided by select Indian banks: Empirical analysis. International Journal of Commerce and Management, 23(1), 56-68.

Sureshchandar, G. S., Rajendran, C., \& Anantharaman, R. N. (2002). The relationship between service quality and customer satisfaction-a factor specific approach. Journal of Services Marketing, 16(4), 363-379.

Surjadjaja, H., Ghosh, S., \& Antony, J. (2003). Determining and assessing the determinants of e-service operations. Managing Service Quality: An International Journal, 13(1), 39-53.

Wolcott, H. F. (1990). Making a study “more ethnographic.” Journal of Contemporary Ethnography, 19(1), 44-72.

Yang, Z., Jun, M., \& Peterson, R. T. (2004). Measuring customer perceived online service quality: scale development and managerial implications. International Journal of Operations \& Production Management, 24(11), 1149-1174.

Zhu, F. X., Wymer, W., \& Chen, I. (2002). IT-based services and service quality in consumer banking. International Journal of Service Industry Management, 13(1), 69-90.

\begin{tabular}{lll}
\hline Construct/Variable & Dimensions & Items \\
\hline Automated & Convenience & All my banking requirements are available in the electronic \\
banking menu options & Electronic banking services are very easy to use. \\
& Electronic banking services have a user-friendly system \\
& Electronic banking services are available $24 / 7$
\end{tabular}


My bank's automated services are trustworthy

I feel secure that my private information will not go to another party

Commitment

The confidentiality of customer data is ensured

I intend to maintain the relationship with my bank indefinitely

My relationship with my bank deserves maximum efforts to maintain

The relationship that I have with my bank is something I am very committed to

I am very proud to have this bank as a financial service provider

Trust

My bank can be trusted always.

My bank can be counted on to do what is right

My bank has a high moral soundness.

My bank can be relied on to keep its words.

I have feeling of trust in my bank

\section{Appendix}

(M. A. Al-Hawari, 2011) 